\title{
Frequency Analysis and Sismic Vulnerability Index by Using Nakamura Methods For Microzonation at Prambanan Temple and Its Surrounding Area, Yogyakarta Province, Indonesia
}

\author{
Fathul Mubin ${ }^{1, \mathrm{a}}$ and Budi Eka Nurcahya ${ }^{1, \mathrm{~b}}$ \\ ${ }^{1}$ Geophysics Sub-Department, Physics Department, FMIPA, UGM \\ ae-mail: mubinugm@gmail.com, be-mail: budiekanurcahya@yahoo.com.
}

\begin{abstract}
In 2006 a large earthquake ever occurred in the province of Yogyakarta, which caused considerable damage. This is the basis need to investigate the seismic vulnerability index in around of the earthquake zone. This research is called microzonation of earthquake hazard. This research has been conducted at the site and surrounding of Prambanan. The reason this research needs to be done because in the event of an earthquake in 2006, there was damage to the temples at Prambanan temple complex and its surroundings. In this research, data collection carried out for 60 minutes using three component seismograph measurements at 89 points with spacing of 1000 meters. The data recorded in time function were analyzed using the spectral ratio method, known as the Horizontal to Vertical Spectral Ratio (HVSR). Results from this analysis are dominant frequency $\left(F_{g}\right)$ and amplification factor $\left(A_{g}\right)$ are used to obtain seismic vulnerability index. The results of research showed the dominant frequency range from 0.2 to $21 \mathrm{~Hz}$ and the amplification is in interval from 0.2 to 7 . Interval value for seismic vulnerability index is 0.1 to 28.
\end{abstract}

Keywords - amplification factor, dominant frequency, microzonation, seismic vulnerability index

\section{INTRODUCTION}

In 2006 a large earthquake ever occurred in the province of Yogyakarta, which caused considerable damage. This is the base of need to investigate the seismic vulnerability index in around of the earthquake zone. This research is called microzonation of earthquake hazard. This research has been conducted at the site and surrounding of Prambanan. The reason this research needs to be done because in the event of an earthquake in 2006, there was damage to the temples at Prambanan temple complex and its surroundings.

Yogyakarta province is located in the southern part of Java island which has a unique geological structure (Fig. 1). The geological structure of Yogyakarta showed significant effects of collisions between two major plates, namely Eurasian and Indo-Australian plates. The Indo-Australian plate is subducting beneath Eurasian plate perpendicularly with estimated convergence rate of $67 \mathrm{~mm} / \mathrm{yr}$ along the Java arc with dip about $60^{\circ}$ and the deepest earthquake record is about $670 \mathrm{~km}$ beneath the Java Sea. This subduction led to rise of Java magmatic lanes, the outside arc lanes, and ocean trough in the south of Java Island. The consequences of Yogyakarta lies within the geological structure is a high vulnerability of multi disaster

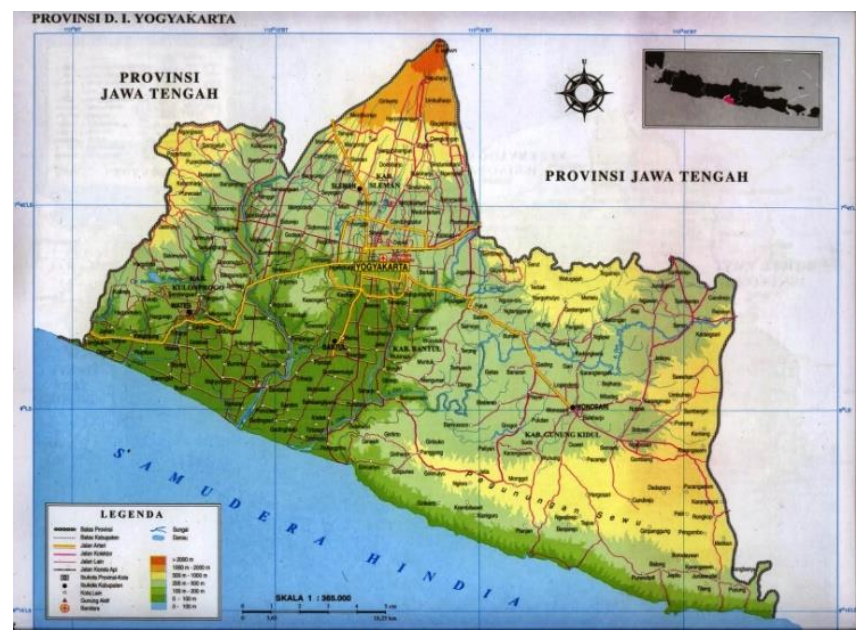

Figure 1. Map of Yogyakarta province, Java island, Indonesia

Prambanan temple or Roro Jonggrang is the biggest complex hindust temple in Indonesia (Fig. 2). It was built during the Sanjaya Dynasty in the 9th century, dedicated to the Trimurti, the expression of God as the Creator (Brahma), the Preserver (Vishnu) and the Destroyer (Shiva). The temple compound is located approximately 17 kilometres northeast of the city of Yogyakarta on the boundary between Central Java and Yogyakarta provinces. The temple was rediscovered in 1818, apparently after being covered in volcanic ash from Mount Merapi volcano for hundreds of years

Seismic microzonation is the process of division of areas that potentially have the damage caused by seismic activity and earthquakes taking into account the geological and physical characteristics of the sediment layer. Characteristics considered include ground shaking (ground shaking), vulnerability to collapse (liquefaction susceptibility), ground movements and others. Seismic microzonation also useful for seismic disaster mitigation because can provide very important information for development planning in order to be able to withstand 
earthquake shocks, such as the dominant frequency and the amplification.

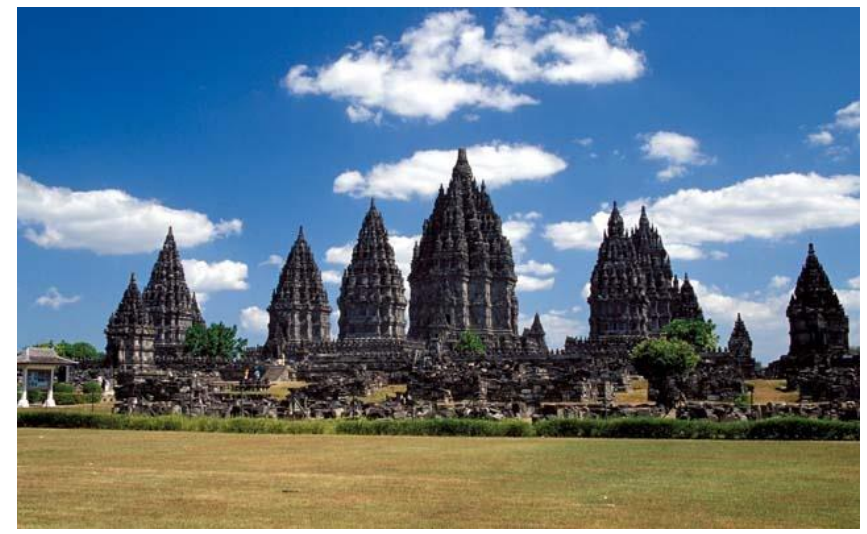

Figure 2. Prambanan temple complex

Microzonation analysis can be performed using HVSR method (Horizontal to Vertical Spectral Ratio). This method is one of the easiest and most inexpensive ways to understand the properties of the subsurface layer structure without causing disruption to the structure. HVSR method is a method that are used as an indicator of subsurface structure, which shows the relationship between the ratio of the spectrum of $\mathrm{H} / \mathrm{V}$ with the ellipticity curve of Rayleigh waves. Comparison of the spectral of $\mathrm{H} / \mathrm{V}$ is the ratio between the amplitude of Fourier spectral of horizontal and vertical components of microtremor [1]. Rayleigh Ellipticity is the ratio of the amplitude of spectral components of the horizontal to the vertical [2]. Ellipticity curve that is used in earthquake engineering are to determine the fundamental frequency of earthquake location, and is very responsive to the location and depth of a layer.

Geologically, Prambanan Temple and its surrounding areas located on top of Merapi Quatenary sediment and its near about the Opak fault where is prone to damage from earthquakes.

\section{DATA AND METHODOLOGY}

The methods applied on this study are evaluation on geological and seismological secondary data. Evaluations on microtremor data is also carried out including analysis of $\mathrm{H} / \mathrm{V}$ amplification ratio, dominant frequency and seismic vulnerability index.

\section{A. Geological and Tectonic Setting}

The geological profile for Prambanan temple and its surrounding is situated at geomorphologic unit of a gentle slope of southeast Merapi volcano, composed of breccia, tufaceous and volcanic gravels [3]. The western part of this complex meets a creek river valley. On the other hand, eastern part of the temple was found in the denudated flat area. On other side, the areas is controlled by the active northwest - southeast normal left lateral slip fault so called the Opak active fault activities. Seen from the geological point view, the Prambanan temple complex is located in the tensional zone (see Fig. 3).

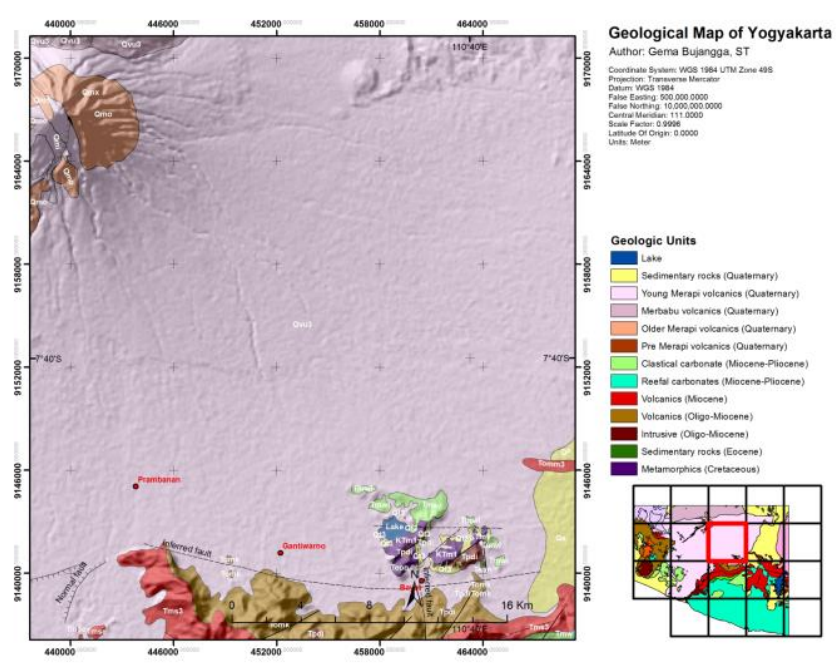

Figure 3. Geological map for the study area, Yogyakarta province.

\section{B. Microtremor Survey}

Microtremor surveys can be done in two ways [4]. The first approach is the recording made simultaneously on two or more locations. One of the recording tools must be put in the area of hard rock (hard rock) that does not indicate a strengthening of the frequency due to ground movement. Ratio spectra obtained at other places (soft rock) will be compared with that recorded on the hard rock that will get the response to microtremor site. The problem with the way this survey will be difficult because it requires the area or areas that have a place with a hard rock as a comparison. The other problem is this method requires relatively large earthquakes that are not suitable for areas with low seismicity.

The second way was introduced by Nakamura [5], he named it $\mathrm{H} / \mathrm{V}$ spectral ratio. Nakamura technique only need one station, this is because the spectra ratio of horizontal and the vertical components recorded at the same site (H/V spectral ratio).This technique attractive since it gives ease of data collection and it can be applied in area of low or even no seismicity. Nakamura assumes that the $\mathrm{H} / \mathrm{V}$ ratio reflects the amplification of ground motion. With this method of measurement does not need to be done with the requirements of the hard rock.

In this research, data collection carried out for 60 minutes using three components seismograph measurements at 90 points which covered $102299.72 \mathrm{~km}^{2}$ area, with spacing of 1000 meters in Prambanan district, Yogyakarta. The data recorded in time function were analyzed using the spectral ratio method, known as the Horizontal to Vertical Spectral Ratio (HVSR). 


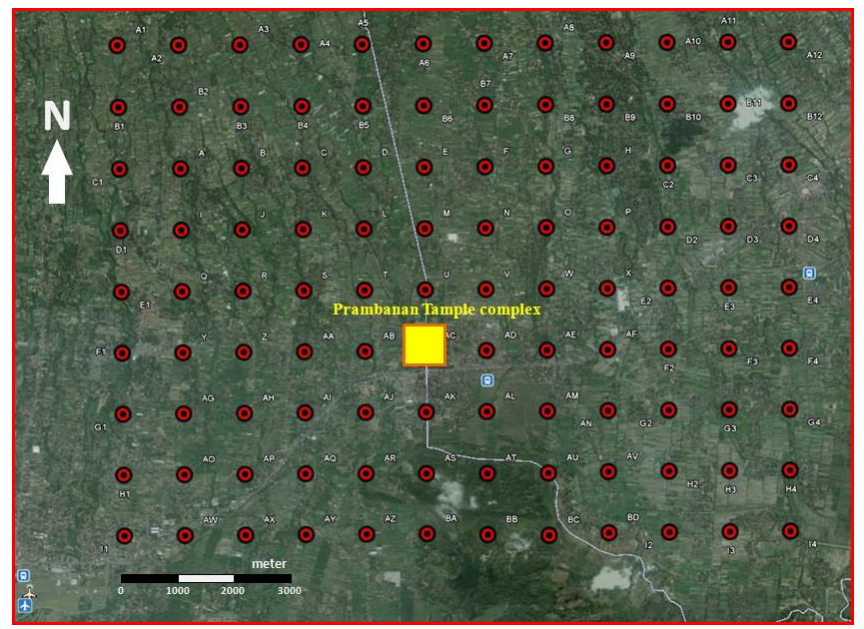

Figure 4. Map of research location in Prambanan district, Yogyakarta province.

Fig. 4 shows area of microseismic survey of the research. The measurement area is located in Prambanan district, Yogyakarta province. In the study area, there are several cultural heritage, namely the temples, including: Prambanan Temple, Plaosan Temple, Ratu Boko Temple, etc. Prambanan Temple is the greatest among them, there are damage at the temple sites during the Yogyakarta earthquake in 2006.

\section{Nakamura (HVSR) Technique}

HVSR method was first introduced by Nogoshi and Igarashi [6] which suggested relevance between the ratio of horizontal and vertical components of the Rayleigh wave ellipticity curve, which is then refined by Nakamura which suggested that the ratio of spectrum as frequency function was related with site transfer function for Shear wave. Nakamura [5] showed that the ratio between horizontal and vertical components of ambient noise recording is closely related to the original frequency of the ground, so it will obtain an amplification factor.

Function of $Z(t), N(t)$, and $E(t)$ are recording results of vertical component microseismic, horizontal component (north-south and east-west). Then, the comparison of value of amplitude vertical to horizontal component, contained in the equations:

$$
\begin{aligned}
& \tilde{Z}(\omega)=\frac{1}{C_{\psi}} \int_{-\infty}^{+\infty} \int_{-\infty}^{+\infty} \int_{-\infty}^{+\infty} W_{Z(t)}(u, s) \psi\left(\frac{t-u}{s}\right) \exp (-i \omega t) \frac{d s}{s^{2}} \frac{d u}{\sqrt{s}} d t \\
& \tilde{N}(\omega)=\frac{1}{C_{\psi}} \int_{-\infty}^{+\infty} \int_{-\infty}^{+\infty} \int_{-\infty}^{+\infty} W_{N(t)}(u, s) \psi\left(\frac{t-u}{s}\right) \exp (-i \omega t) \frac{d s}{s^{2}} \frac{d u}{\sqrt{s}} d t \\
& \tilde{E}(\omega)=\frac{1}{C_{\psi}} \int_{-\infty}^{+\infty} \int_{-\infty}^{+\infty} \int_{-\infty}^{+\infty} W_{E(t)}(u, s) \psi\left(\frac{t-u}{s}\right) \exp (-i \omega t) \frac{d s}{s^{2}} \frac{d u}{\sqrt{s}} d t
\end{aligned}
$$

The H/V spectral ratio $\left[T_{H / V}(\omega)\right]$ was obtained by dividing the average spectra of the horizontal component of sediment site $\left[S_{S N}(\omega)+S_{E W}(\omega)\right]$ by the spectrum of the vertical component $\left[S_{V}(\omega)\right]$ of the sediment site :

$$
T_{\frac{H}{V}(\omega)}=\frac{\left[S_{S N}(\omega)+S_{E W}(\omega)\right] / 2}{S_{V}(\omega)}
$$

Based on Nakamura Idea, amplitude effect of source can be estimated by the ratio :

$$
A_{S}=V_{S} / V_{B} \text { and } S_{E}=H_{S} / H_{B},
$$

where the amplitude spectrum of the vertical component of motion at the surface and amplitude spectrum of the vertical component of motion at the half space defined as $V_{S}$ and $V_{B}$. Nakamura also estimates site effect of interest in earthquake engineering $\left(S_{E}\right)$, where $H_{S}$ and $H_{B}$ are Fourier amplitude spectra of the horizontal component of motion at the surface and the base of soil layer using assumption:

$$
H_{B} / V_{B}=1 \text {. }
$$

We can calculate the site affect spectral ratio $\left(S_{M}\right)$ as

$$
S_{M}=\frac{S_{E}}{A_{S}}=\frac{H_{S} / V_{S}}{H_{B} / V_{B}}=H_{S} / V_{S} \text {. }
$$

Assumption $H_{B} / V_{B}=1$ was verified by Nakamura experimentally using microtremor measurement at depth in a borehole. A more detailed about this method can be found in Lermo dan Chaves-Garcia [7].

Then, seismic vulnerability $\left(K_{g}\right)$ is an index that shows vulnerability value of a soil layer deformed. Therefore, the seismic vulnerability index is useful for the detection of weak zones (unconsolidated sediment) at the time of the earthquake. Some studies such as [8],[9] showed a good correlation between seismic vulnerability and the distribution of damage caused by the earthquake.

Vulnerability index focused on the strain was defined [10]. $K$ values in $10^{-6} /\left(\mathrm{cm} / \mathrm{s}^{2}\right)$ are defined to estimate the strain in the unit of $10^{-6}$ at particular parts of the structures, by multiplying the maximum acceleration at the engineering basement and the $K$ value. These $K$ values are defined for ground and various structures, as $K_{g}$ value for ground, $K_{j}$ value for embankment, $K_{s}$ value for rigid frame structure and $K_{b}$ value for building. As peculiar $\mathrm{K}$ value, $K_{d}$ value for derailment is defined. In this section, $K_{g}$ is introduced. Formula to calculate seismic vulnerability $\left(K_{g}\right)$ can be written as: 


$$
K_{g}(e)=\frac{A_{g}^{2}}{F_{g}},
$$

where $A_{g}$ is amplification factor and $F_{g}$ is dominant frequency of surface ground. The effective strain can be estimated by multiplying $\mathrm{Kg}(\mathrm{e})$ value with maximum acceleration of basement ground in $\mathrm{Gal}\left(=\mathrm{cm} / \mathrm{s}^{2}\right)$.

\section{Data Processing}

In processing data, we used Geopsy software. This software contains information of recording time, the amount of data, and other supporting data. The result is a spectrum at each station will then be analyzed to obtain the HVSR peak value $\left(A_{g}\right)$ and dominant frequency $\left(F_{g}\right)$. At the time of processing using Geopsy software, data are divided into several windows (Figure 3). If the data are large enough sorting windows are automatically provided by the software. Windowing is the process to sort data between the tremor signals and transient event (especially specific sources such as footsteps and vehicle passes). The function of this process is to avoid the processing of transient events in the analysis. Comparison between the Short Term Average (STA) and Long Term Average (LTA) and also using anti triggering logarithm is the way to detect transient signals. STA is the average value of short-term amplitude (0.5-2.0 seconds) and LTA is an amplitude value of the average long term (>10 seconds). When comparison result from STA/LTA exceeds a predetermined threshold, then it can be referred to as event.

The collected data have been processed using the GEOPSY software developed within the framework of the great European project SESAME. The H/V spectral ratios were computed according to the following methodology: (1) baseline correction; (2) band-pass filtering to retain the frequencies in the range from 1 to $25 \mathrm{~Hz}$; (3) windows of 10 $s$ length were automatically selected using an anti-STA/LTA trigger algorithm and tapered with a 5\% cosine function before the computation of spectra; (4) Fourier spectra were calculated for each noise component and smoothed using Konno-Omachi window having a smoothing constant bvalue of 40 ; (5) the resulting spectral amplitudes of horizontal components were geometrically averaged and divided by the vertical spectra to calculate the $\mathrm{H} / \mathrm{V}$ function. Moreover, stability of the peak in the H/V curve have been checked through three tests conducted at every measuring point, where the same frequency peaks were picked for each site at different times [11].

The next step is the processing that is composed of the FFT process, involving the smoothing process. Smoothing process is done by using algorithms Konno and Omachi [12] with bandwidth $b$ coefficient of 40. It is also made the process of cosine taper to minimize the effects of borders or boundaries due to window selection process. The Konno and Ohmachi smoothing is defined by the following function:

$$
W b(f, f c)=\left(\frac{\sin \left(b \log 10\left(\frac{f}{f c}\right)\right.}{b \log 10\left(\frac{f}{f c}\right)}\right)^{4},
$$

Where $f$ is the frequency, $f_{\mathrm{c}}$ is the central frequency and $b$ is the bandwidth coefficient.

An example of one of data collection can be seen in Fig, 5 . The result is a spectrum at each measurement data will then be analyzed to obtain the HVSR peak value $\left(A_{g}\right)$ and dominant frequency $\left(F_{g}\right)$.

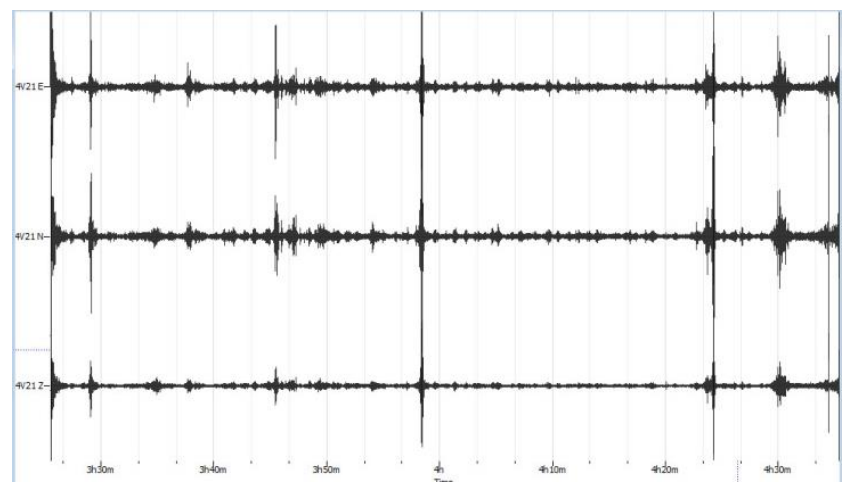

Figure 5. An example raw data from microseismic measurement.

At Fig. 6, data collection are processed using GEOPSY software, data is divided into several windows. If the data is large enough sorting window is automatically provided by the software. Windowing is the process to sort data between the tremor signals and transient event (especially specific sources such as footsteps and vehicle passes).

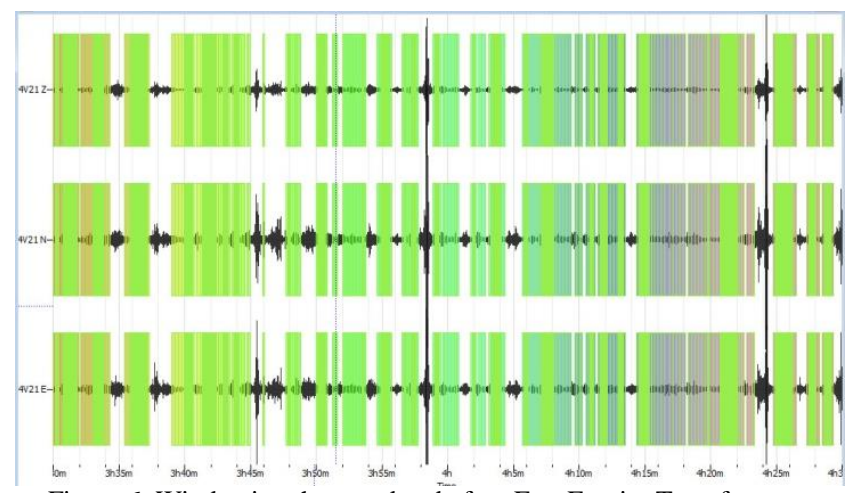

Figure 6. Windowing the raw data before Fast Fourier Transform.

\section{RESULTS AND DISCUSSION}

\section{A. HVSR Spectrum Ratio}

HVSR spectrum obtained from analysis of microtremor signal recording using Geopsy software. This process can be determined values of $A_{g}$ and $F_{g}$ for each measurement point. Figure 4 shown there are two dotted lines above and below which is standard deviation for all values of the ratio of the 
resulting spectrum. The line in the middle is the average value of the Fast Fourier Transform (FFT) analysis of the entire value of $\mathrm{H} / \mathrm{V}$ ratio, while the thin line is color full curves $\mathrm{H} / \mathrm{V}$ spectrum ratio of each window (Fig. 7).

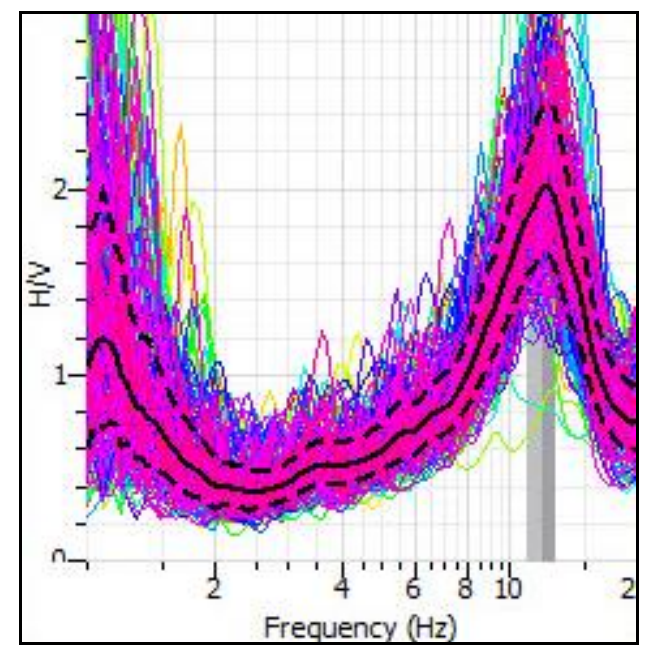

Figure 7. An example of $\mathrm{H} / \mathrm{V}$ spectral ratio.

\section{B. Dominant Frequency Distribution $\left(F_{g}\right)$}

According to map of dominant frequency (Fig. 8), the dominant frequency $F_{g}$ varies from $0.2 \mathrm{~Hz}$ to $21 \mathrm{~Hz}$ within the study area. These low values indicate large thickness of sediments. While, there are some localized areas that have higher values of f0 (up to $20 \mathrm{~Hz}$ ) distributed throughout the central and southeastern parts of the area. The number of data records mostly have dominant frequency values in interval $0.1-4 \mathrm{~Hz}$, there are 53 records (up to $59.5 \%$ ) within the study area (Fig. 9). It can be understood qualitatively that, the study area has relatively uniform sediment thickness.
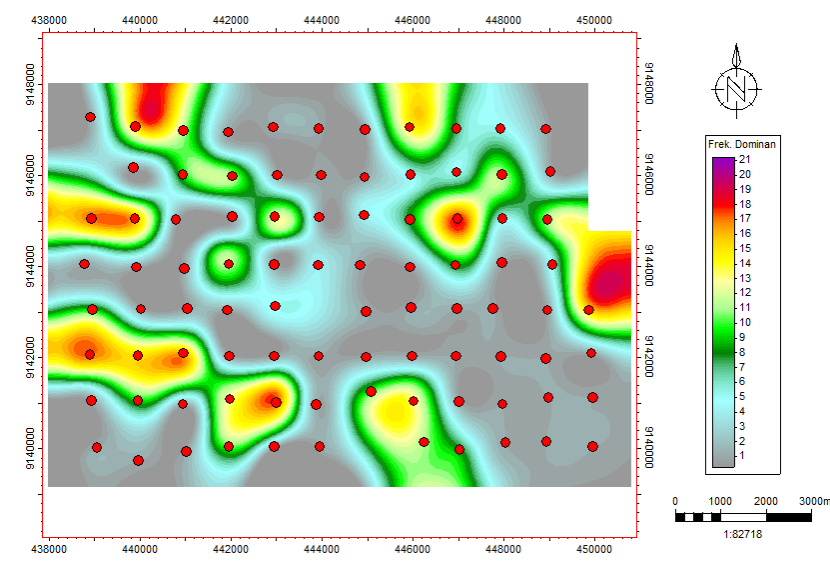

Figure 8. Map of dominant frequency distribution at Prambanan temple and its surrounding area.

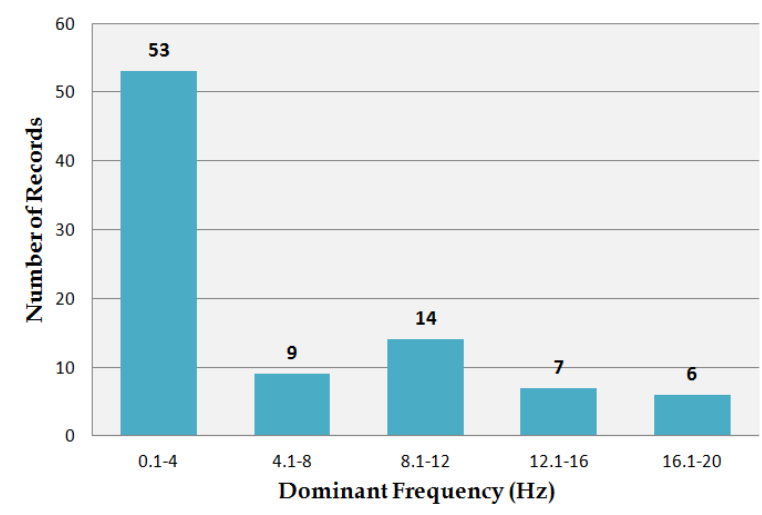

Figure 9. Histogram of relation between number of records with dominant frequency $(\mathrm{Hz})$.

\section{H/V Peak Value Distribution}

Map of $\mathrm{H} / \mathrm{V}$ peak value distribution in the research has $\mathrm{H} / \mathrm{V}$ peak values ranges from 0.2 to 7 . Contour map for $\mathrm{H} / \mathrm{V}$ amplitude ratio (The maximum amplification) (see Fig. 10) illustrated that, the western and northern parts of the area have values less than 2.5 while the highest value is the southeast (more than 4). As for Prambanan temple area has $\mathrm{H} / \mathrm{V}$ value of 2 , these values increases towards the southeast of Prambanan temple (Klaten regency area) where it has a value more than 5 .

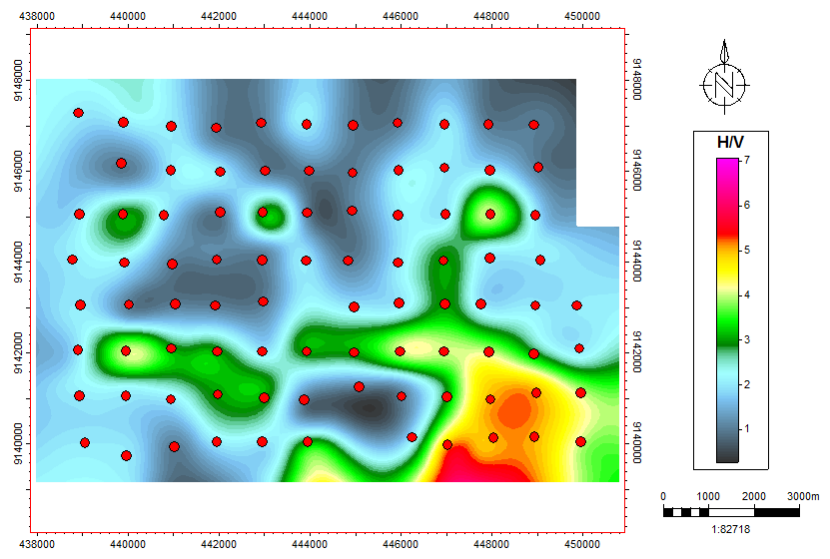

Figure 10. Map of H/V peak values distribution at Prambanan temple and its surrounding area.

\section{Seismic Vulnerability Index Distribution}

Map of seismic vulnerability distribution in the research has index values ranges from 0.1 to 28 (ee Fig. 11). There are areas which have high susceptibility values in the southeastern part area (high level) (see Fig. 11). The area entered in Klaten regency, Central Java province. As for the area of Prambanan temple has interval of vulnerability value from 5-6. The number of data records mostly have seismic vulnerability values in interval $0.1-5$, there are 63 records 
(up to $71 \%$ ) within the study area (see Fig. 12). However, there are 4 records that have vulnerability values of more than 20 (high level).
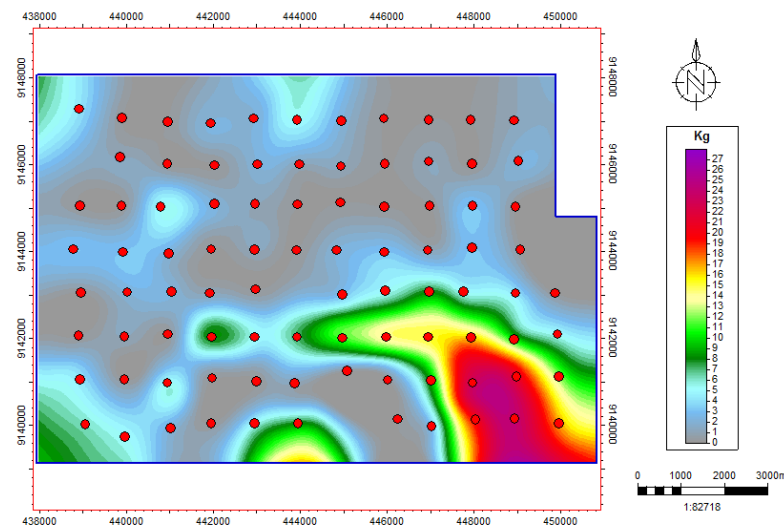

Figure 11. Map of seismic vulnerability distribution at Prambanan temple and its surrounding area.

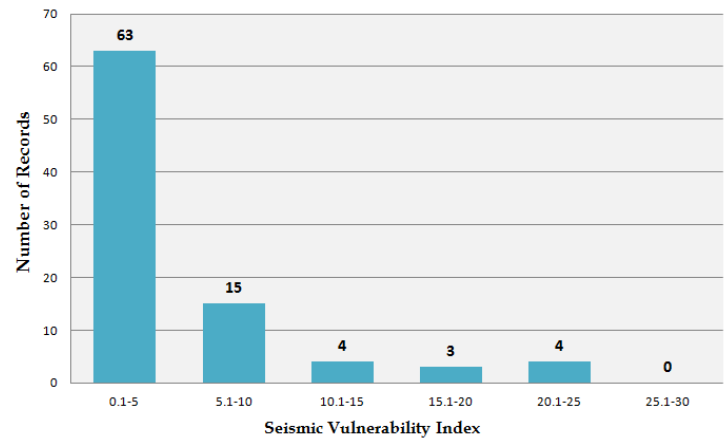

Figure 12. Histogram of relation between number of records with seismic vulnerability.

\section{E. Elevation Distribution}

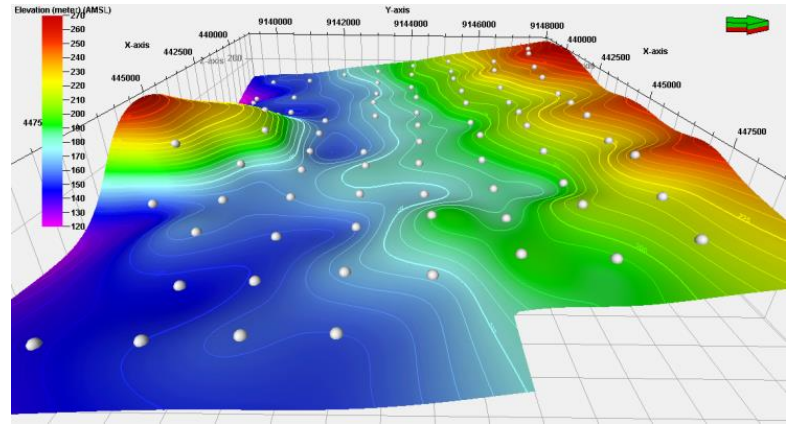

Figure 13. Map of elevation distribution at Prambanan temple and its surrounding area.

As for the value of elevation on measurement location can be seen in Fig. 13. Measurement areas are lowland and highland. The highland areas are on south and north, lowland areas are on west and east.

\section{CONCLUSIONS}

Based on research results, dominant frequency $\left(F_{g}\right)$ values for at the reserach area are in intervals from 0.2 to 21 $\mathrm{Hz}$. This suggests that the study area has high value of $F_{g}$ $(>10 \mathrm{~Hz})$. HVSR peak values are in interval values from 0.2 to 7 . The seismic vulnerability index values are in interval from 0.1 to 28 . Based on a map of seismic vulnerability distribution can be interpreted that the research area has a high vulnerability index. There are areas which have a high susceptibility value is in the east area. The area entered in Klaten regency, Central Java province. As for the area of Prambanan temple has interval of vulnerability value from 5 to 6 .

The value of $F_{g}, \mathrm{H} / \mathrm{V}$, and high seismic vulnerability indicates that the research area have high levels of earthquake damage effect to buildings.

\section{REFERENCES}

[1] K. Aki, and P. G. Richard, A Quantitative Seismology: Theory and Methods, vol 1, W.H. Freemann, New York, 1980.

[2] A. Susilo, and P. Winoto, "Microtremor Analysis of Brawijaya University Area Using Horizontal to Vertical Spectral Ratio Methods", Jurnal Geofisika [J], vol. 1, pp. 17-24, 2010.

[3] W. Rahardjo, Sukandarumidi, and H. M. D. Rosidi, Peta Geologi Lembar Yogyakarta, Jawa, Pusat Penelitian dan Pengembangan Geologi, Bandung, 1995.

[4] S. Mukhopadhyay and P. Bormann, "Low cost seismic microzonation using microtremor data: an example from Delhi, India". Journal of Asian Earth Sciences, 24, 3,271-280, 2004.

[5] Y. Nakamura, "A Method for Dynamic Characteristics Estimation of Subsurface using Microtremor on the Ground Surface", Q.Rep., RTRI:30, pp. 25-33,1989.

[6] M. Nogoshi and T. Igarashi, "On the Amplitude Characteristics of Microtremor (Part 2)". Journal of the Seismological Society of Japan, 24, 26-40, 1971

[7] J. Lermo and J. Chavez-Garcia, "Site effect evaluation using spectral ratios with only one station", Bull. Seism. Soc. Am. 83, 1574-1594, 1993

[8] Daryono, Sutikno, Sartohadi, Dulbahri, and Brotopuspito, "Pengkajian Local Site Effect di Graben Bantul Menggunakan Indeks Kerentanan Seismik Berdasarkan Pengukuran Mikrotremor", Jurnal Kebencanaan Indonesia, Vol. 2 No. 1, Pusat Studi Bencana (PSBA) Universitas Gadjah Mada, Yogyakarta, 2009.

[9] Y. Nakamura, "Clear Identification of Fundamental Idea of Nakamura's Technique And It's Application", World Conference of Earthquake Engineering, 2000.

[10] Y. Nakamura, "On the H/V Spectrum", The $14^{\text {th }}$ World Conference on Earthquake Engineering October 12-17, Beijing, China, 2008.

[11] M. S. Fnais, K. Abdelrahman, and A. M. Al-Amri, "Microtremor measurements in Yanbu city of Western Saudi Arabia: A tool for seismic microzonation", Journal of King Saud University (Science) vol. 22 , pp. $97-110,2010$.

[12] K. Konno and T. Ohmachi, "Ground-Motion Characteristics Estimated from Spectral Ratio between Horizontal and Vertical Components of Microtremor", Bulletin of the Seismological Society of America, Vol. 88, No. 1, pp. 228-241, 1998. 